University of Nebraska - Lincoln

DigitalCommons@University of Nebraska - Lincoln

\title{
Design and application of a polyclonal peptide antiserum for the universal detection of leptin protein
}

\author{
Mark P. Richards \\ United States Department of Agriculture, richards@lpsi.barc.usda.gov \\ Thomas J. Caperna \\ United States Department of Agriculture \\ Theodore $\mathrm{H}$. Elasser \\ United States Department of Agriculture \\ Christopher M. Ashwell \\ United States Department of Agriculture \\ John P. McMurtry \\ United States Department of Agriculture
}

Follow this and additional works at: https://digitalcommons.unl.edu/usdaarsfacpub

Part of the Agricultural Science Commons

Richards, Mark P.; Caperna, Thomas J.; Elasser, Theodore H.; Ashwell, Christopher M.; and McMurtry, John P., "Design and application of a polyclonal peptide antiserum for the universal detection of leptin protein" (2000). Publications from USDA-ARS / UNL Faculty. 694.

https://digitalcommons.unl.edu/usdaarsfacpub/694

This Article is brought to you for free and open access by the U.S. Department of Agriculture: Agricultural Research Service, Lincoln, Nebraska at DigitalCommons@University of Nebraska - Lincoln. It has been accepted for inclusion in Publications from USDA-ARS / UNL Faculty by an authorized administrator of DigitalCommons@University of Nebraska - Lincoln. 


\title{
Design and application of a polyclonal peptide antiserum for the universal detection of leptin protein
}

\author{
Mark P. Richards*, Thomas J. Caperna, Theodore H. Elsasser, \\ Christopher M. Ashwell, John P. McMurtry
}

U.S. Department of Agriculture, Agricultural Research Service, Livestock and Poultry Sciences Institute, Growth Biology Laboratory, Beltsville, MD 20705-2350, USA

Received 7 February 2000; received in revised form 28 April 2000; accepted 25 May 2000

\begin{abstract}
An epitope-specific polyclonal antiserum was produced in rabbits immunized against a synthetic 15 amino acid peptide (QRVTGLDFIPGLHPV) derived from the coding sequence reported for the porcine leptin gene (GenBank Accession No. U59894). This peptide contains a core sequence comprised of eight amino acids (GLDFIPGL) that is totally conserved in all leptin proteins studied to date. Purified recombinant human, mouse, rat, pig, and chicken leptin proteins were separated by polyacrylamide gel electrophoresis (SDS-PAGE) and electro-blotted onto PVDF membranes. Western blots were developed employing the leptin-specific peptide antiserum with an alkaline-phosphatase-conjugated anti-rabbit IgG second antibody chromogenic system. The peptide antiserum was found to be highly specific for leptin which exhibited an estimated molecular weight of about $16 \mathrm{kDa}$ for all species analyzed. The sensitivity of the Western blot assay was not sufficient to permit the direct detection of leptin in chicken serum or plasma. However, with this assay we were able to detect native leptin protein in an enriched fraction prepared from chicken plasma using a combination of gel filtration and ion exchange column chromatography. Slot blots indicated a potential application of the immunostaining technique for quantitative analysis of leptin protein. Finally, the peptide antiserum was successfully employed to localize leptin protein by immunohistochemical staining of thin sections prepared from adipose (chicken and pig) and liver (chicken) tissue samples. This study is the first to report a polyclonal peptide antiserum that apparently recognizes intact leptin protein, both native and recombinant, regardless of the species of origin. (C) 2000 Elsevier Science B.V. All rights reserved.
\end{abstract}

\footnotetext{
*Corresponding author. Tel.: +1-301-504-8892; fax: +1-301-504-8623.

E-mail address: richards@1psi.barc.usda.gov (M.P. Richards).
} 


\section{Introduction}

Leptin, a polypeptide hormone involved in the regulation of food intake, energy balance and body weight, is encoded by the obese gene $(o b)$ that has recently been identified and characterized in a number of animal species as well as in humans [1]. After intracellular processing of the 167 amino acid pro-hormone to cleave a 21 amino acid signal peptide segment, the mature form of leptin is secreted into the bloodstream where it circulates as a 146 amino acid $(16 \mathrm{kDa})$ protein [1]. Crystal structure and NMR studies have characterized leptin as a four-helix bundle cytokine containing a single disulfide bond $\left(\mathrm{Cys}_{96}-\mathrm{Cys}_{146}\right)$ that is essential, both to its structure and to its function $[2,3]$. In mammals, leptin is expressed primarily in white adipose tissue, although other tissues such as gastric epithelial lining, placenta, muscle, brain, pituitary, and hypothalamus have also been found to be sites of leptin expression [1]. In chickens, leptin is produced by liver and adipose tissue, with liver being the predominant site of expression [4,5]. Leptin has been reported to function in the regulation of appetite, energy metabolism, fertility, and in the maintenance of body weight by acting as a peripheral hormone 'sensor' for the size of adipocyte energy (lipid) stores [6].

Receptors, similar to those of the class I cytokine receptor super-family, have been identified for leptin in the central nervous system as well as in peripheral tissue locations [7]. In the hypothalamus, leptin has been reported to suppress neuronal levels of neuropeptide Y (NPY) and agouti-related peptide (AGRP), while stimulating the production of proopiomelanocortin (POMC) [8]. Together, these actions and other less well characterized neuroendocrine signaling pathways bring about a suppression of feeding behavior as well as changes in energy expenditure and body weight. Although leptin genes have been identified in sheep, cattle, pigs and chickens, relatively little is known about its specific role(s) in regulating appetite, energy metabolism, and body weight in farm animals $[9,10]$.

Methodologies for the assay of leptin protein in serum or plasma (i.e., radioimmunoassay, RIA, and enzyme-linked immunoassay, ELISA) have been developed primarily for the determination of rodent or human leptin proteins. However, the antisera and antibodies employed in these assays exhibit varying degrees of species-specificity that constrains their application to accurately measure leptin protein in samples obtained from a broader range of animal species. The objective of this work was to develop an antiserum that would be useful in the immunological detection of leptin protein without regard to its species of origin. To do this we compared the published amino acid sequences derived from the coding sequences for all reported leptin genes and determined unique regions of conservation (Fig. 1). We chose a specific sequence in the $\mathrm{AB}$ loop region of porcine leptin and synthesized a 15 amino acid peptide against which a polyclonal antiserum was produced by immunizing rabbits with a KLH-conjugated peptide antigen. Our results, reported here, detail the use of this polyclonal peptide 


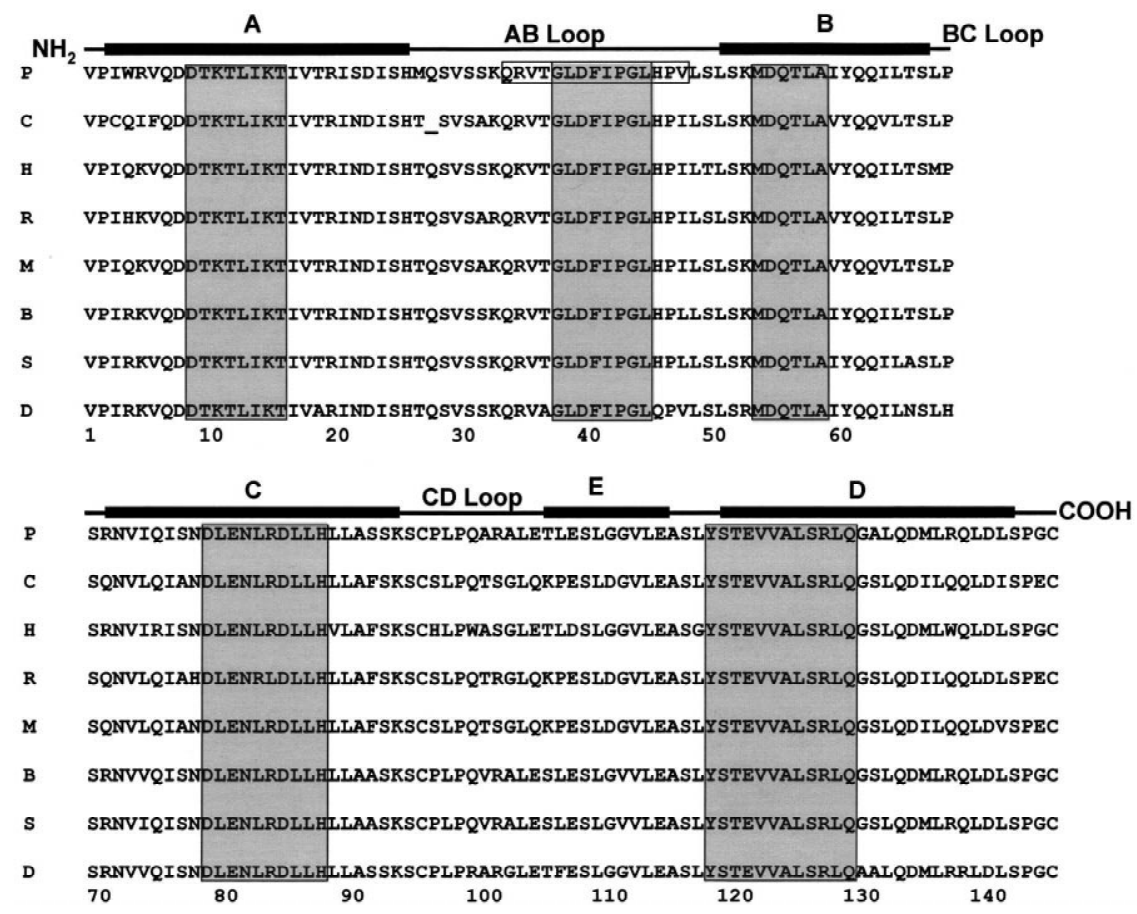

Fig. 1. Amino acid sequence comparison for pig $(\mathrm{P})$, chicken $(\mathrm{C})$, human $(\mathrm{H})$, rat $(\mathrm{R})$, mouse $(\mathrm{M})$, bovine (B), sheep (S) and $\operatorname{dog}(\mathrm{D})$ leptin proteins (mature form without the signal peptide sequence). Amino acid sequences were derived from gene coding sequence data deposited in GenBank or from a previous report [2]. Shaded boxes indicate contiguous, totally conserved regions of amino acid sequence within the protein. The unshaded box in the pig (P) leptin sequence (amino acids 34-48) defines the position of the 15 amino acid peptide that was used to generate the peptide antiserum for this study. Also indicated are the $\alpha$-helical (A-E) and interconnecting (loop) regions in the leptin protein structure.

antiserum in the detection of recombinant and/or native leptin protein from different animal species.

\section{Materials and methods}

\subsection{Materials}

Recombinant human and mouse leptin were purchased from CalBiochem (La Jolla, CA, USA), recombinant rat leptin was purchased from R\&D Systems (Minneapolis, MN, USA), recombinant chicken leptin was provided by Dr. A.F. Parlow (National Hormone and Pituitary Program, Torrance, CA, USA), recombinant porcine leptin was supplied by Dr. Tim Ramsay (USDA, Growth Biology Laboratory, Beltsville, MD, USA) and a recombinant bovine leptin/glutathione- $S$-transferase fusion protein was 
kindly provided by Dr. Roger Stone (USDA, ARS, Clay Center, NB, USA). All purified recombinant leptin proteins were reconstituted in phosphate buffered saline (PBS) at $\mathrm{pH}$ 7.4. Chicken plasma was obtained by cardiac puncture of 8-week-old male broilerbreeder birds. Tissue samples of liver, subcutaneous fat, and abdominal fat were obtained from 5-month-old, cross-bred (Poland China $\times$ Landrace) gilts weighing approximately $80 \mathrm{~kg}$ and from 4-week-old male broiler-breeder chickens weighing approximately $1.1 \mathrm{~kg}$. All studies involving the use of animals were conducted in accordance with research protocols approved by the Beltsville Animal Care and Use Committee.

\subsection{Peptide synthesis and antiserum production}

Peptide synthesis and antiserum production were conducted according to standard and proprietary protocols (GenoSys Biotechnologies Inc., The Woodlands, TX, USA). Briefly, a peptide corresponding to a portion of the porcine leptin protein sequence $\left({ }_{34}\right.$ QRVTGLDFIPGLHPV $\left._{48}\right)$ was synthesized using a solid phase support and FMOC chemistry. Two milligrams of this peptide was conjugated to $150 \mathrm{mg}$ of keyhole limpet hemocyanin $(\mathrm{KLH})$ using a water soluble carbodiimide. The KLH-peptide conjugate was purified by gel filtration chromatography and freeze dried. After reconstitution in deionized water, the conjugate was mixed with either complete or incomplete Freund's adjuvant just prior to immunization of two New Zealand white rabbits. Twelve separate injections of the peptide-KLH conjugate were made for each rabbit at 2-week intervals. Each injection was divided among multiple subcutaneous sites and delivered a total of $0.1 \mathrm{mg}$ of peptide. The initial immunization was given in complete Freund's adjuvant and all subsequent (booster) immunizations were given in incomplete Freund's adjuvant. Blood (yielding 25-30 $\mathrm{ml}$ of serum per rabbit) was collected prior to immunization and at 2-week intervals commencing on the seventh week following the initial immunization. Serum antibody titer (determined by ELISA using the peptide antigen) rapidly rose to 1:50,000 and held constant at that level throughout the remaining immunization period.

\subsection{Column chromatography}

Neat chicken plasma $(350 \mathrm{ml})$ was divided into $50 \mathrm{ml}$ aliquots and fractionated on a column $(5.0 \times 70 \mathrm{~cm})$ packed with Sephacryl S-300 HR (Amersham Pharmacia Biotech, Piscataway, NJ, USA) and equilibrated with PBS at $\mathrm{pH}$ 7.4. Pooled leptin-containing fractions were concentrated by ultrafiltration (YM3 membrane, Amicon Inc., Beverly, MA, USA) and applied to a second column $(2.5 \times 90 \mathrm{~cm})$ packed with Sephadex G-50 and equilibrated with $\mathrm{PBS}$ at $\mathrm{pH}$ 7.4. Fractions comprising the second of the three peaks eluting from the G-50 column were pooled, concentrated by ultrafiltration, diluted (1:100 in $25 \mathrm{mM}$ Tris- $\mathrm{HCl}, \mathrm{pH} 8.0)$, and applied to a third column $(5.0 \times 5.0 \mathrm{~cm})$ packed with DEAE-Sephacel (Amersham Pharmacia Biotech) equilibrated with $25 \mathrm{mM}$ Tris- $\mathrm{HCl}$, pH 8.0. Proteins were eluted with a linear $500 \mathrm{ml}$ gradient of $0-250 \mathrm{mM}$ $\mathrm{NaCl}$ in $25 \mathrm{mM}$ Tris- $\mathrm{HCl}, \mathrm{pH}$ 8.0. Pooled fractions containing leptin were concentrated and desalted by repeated ultrafiltration against deionized water prior to Western blot analysis (see below). Potential leptin-containing fractions from chicken plasma were 
identified at each step of the chromatographic procedure by determining the elution characteristics of a human recombinant leptin standard subjected to identical chromatographic conditions.

\subsection{Western blot analysis}

Recombinant leptin proteins (200 ng per lane) and the leptin-enriched fraction prepared from chicken plasma were subjected to SDS-PAGE using 13\% polyacrylamide separating gels under reducing conditions according to the method of Laemmli [11]. Separated proteins were transferred from the gels to PVDF membranes (Immobilon-P, Millipore Corp., Bedford, MA, USA) using a semi-dry electro-blotting system (Bio-Rad Laboratories, Hercules, CA, USA) for $1 \mathrm{~h}$ at 16-24 V in a Tris-glycine buffer containing $20 \%$ methanol. The blots were stained for total protein with Coomassie blue prior to blocking with BSA (Cat. \#A7888, Sigma, St. Louis, MO, USA). The blots were then incubated with diluted peptide-antiserum (1:6000) followed by an alkaline phosphatase-conjugated second antibody directed against rabbit IgG (Sigma). Immunoreactive bands were visualized with a color generating system comprised of an alkaline phosphatase substrate, 5-bromo-4-chloro-3-indoyl phosphate and nitro blue tetrazolium (BCIP/NBT). Tris-saline buffers containing 0.05\% Tween-20, 0.5\% BSA, and 0.5\% gelatin were used for dilutions and all incubations with antiserum and the second antibody.

\subsection{Slot blot analysis}

Recombinant human leptin protein samples were transferred to $0.2 \mu \mathrm{m}$ nitrocellulose membranes using a slot blotting device under light vacuum (Bio-Rad). Leptin protein adsorbed to the membrane was visualized using the immunostaining technique described previously for Western blot analysis with a 1:5000 dilution of the peptide antiserum. Each blot containing varying amounts of human recombinant leptin (10-600 ng per slot) was replicated in six different assays with two to four individual determinations per slot. Blanks containing either no added protein or $1.5 \mu \mathrm{g}$ of BSA served to assess the level of background staining. The blots were scanned and the resulting stained bands quantified using a laser densitometer (Molecular Dynamics, Sunnyvale, CA, USA). Slot volume (band intensity) was plotted against the amount of leptin added to each slot and linear regression analysis was used to fit a line to the combined data points.

\subsection{Immunohistochemistry}

Samples of adipose and liver tissue obtained from chickens and pigs were fixed overnight in Bouin's solution, embedded in paraffin, sectioned at $6 \mu \mathrm{m}$, and the sections mounted on poly-L-lysine coated glass slides. Following deparaffinizing in xylene, tissue sections were rehydrated by passing them through decreasing concentrations of ethyl alcohol to Tris-buffered saline. Endogenous peroxidase activity was eliminated by incubating the sections for $30 \mathrm{~min}$ in methanolic $\mathrm{H}_{2} \mathrm{O}_{2}$. Nonspecific binding was blocked with normal goat serum followed by an overnight incubation with anti-leptin 
peptide-antiserum (1:2000 dilution). Immunoreactive leptin protein was visualized with an avidin-biotin-enhanced horseradish peroxidase method (Vector Laboratories, Burlingame, CA, USA) using diaminobenzadine as the substrate, followed by a light nuclear counter-stain with Gill's hematoxylin.

\section{Results and discussion}

A high-titer, polyclonal peptide antiserum was produced in rabbits that recognizes an epitope containing a specific eight amino acid core sequence (GLDFIPGL) found in the AB loop portion of all known leptin proteins. Although raised against a KLH-conjugated peptide antigen, this antiserum recognizes intact recombinant leptin proteins in a Western blot assay system for a number of different species tested to date including: human, mouse, rat, pig and chicken (Fig. 2, lanes 2-6). Fractionation of plasma using a combination of gel filtration (Sephacryl S-300 and Sephadex G-50) and anion exchange (DEAE-Sephacel) column chromatography followed by concentration of the sample by ultrafiltration, allowed us to detect native chicken leptin (Fig. 2, lane 1). Recombinant bovine leptin (produced as a glutathione- $S$-transferase fusion protein) was also detected using the Western blotting procedure (data not shown).

To evaluate the quantitative nature of immunostaining, different amounts of recombinant human leptin were vacuum blotted onto nitrocellulose membranes using a slot

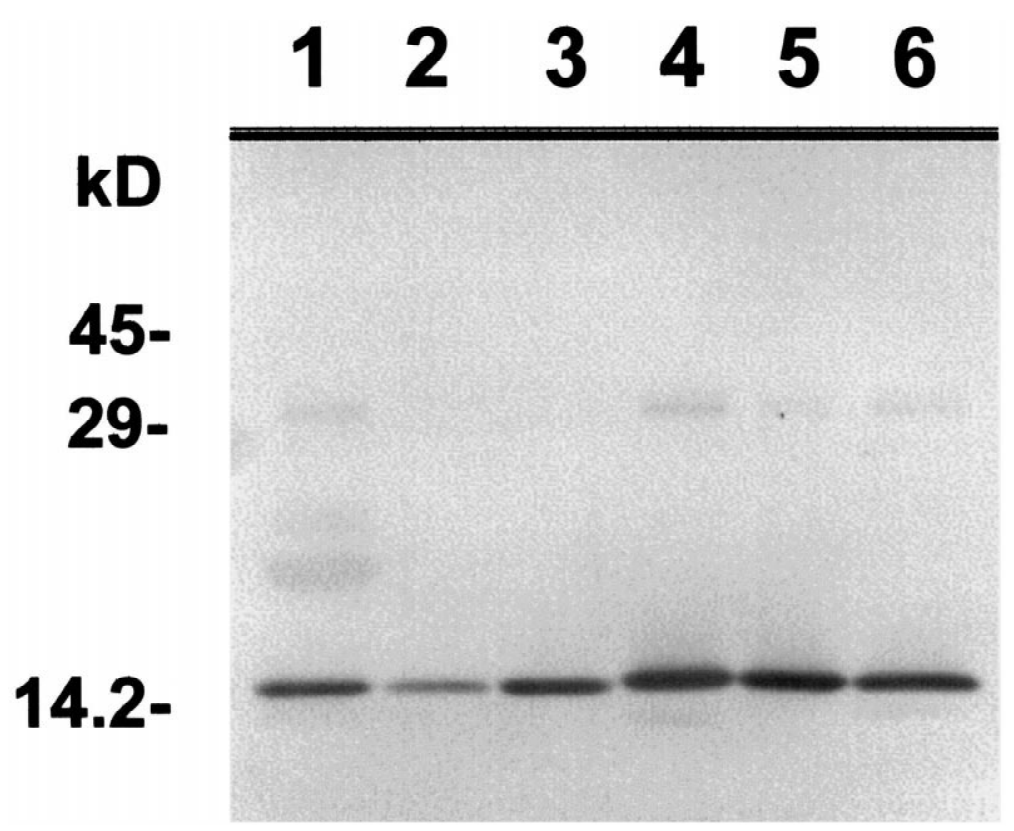

Fig. 2. Western blot analysis of chicken (lane 2), human (lane 3), mouse (lane 4) rat (lane 5), and pig (lane 6) purified recombinant leptin proteins (200 ng per lane). Lane 1 shows an enriched leptin-containing extract from chicken plasma that had been subjected to prior gel-filtration followed by anion exchange chromatographic fractionation. 
blotting device and the bands were developed with the double antibody staining system used for Western blot analysis. With this approach, a standard curve was constructed using 10 to $600 \mathrm{ng}$ of human recombinant leptin (Fig. 3). Band intensity (i.e., slot volume), quantified by scanning laser densitometry, showed a significant linear response $\left(r^{2}=0.914\right)$ between 20 and $500 \mathrm{ng}$ of added leptin protein. These preliminary findings suggest that the peptide antiserum in conjunction with slot blotting may be a useful tool for monitoring the level of leptin protein during purification of recombinant or native proteins. However, sample matrix effects, which can affect the binding of protein to the membranes, may limit the usefulness of this technique to estimating the quantity of leptin in purified or highly enriched samples. Further evaluation is required to determine the utility of this method for the quantification of leptin protein.

Initial determinations of the specific localization of leptin protein were obtained and verified from serial cut sections of paraffin embedded adipose and liver tissue samples incubated with anti-leptin antiserum pre-adsorbed and immuno-neutralized with either the immunization peptide $(10 \mu \mathrm{g} / \mathrm{ml})$ or recombinant human leptin $(1 \mu \mathrm{g} / \mathrm{ml})$. In the pig, the absence of positive immunostaining for leptin in tissues other than those containing adipocytes demonstrated an absence of random, nonspecific binding of the antibody to cell structures not containing leptin. Pre-adsorption of the antibody resulted

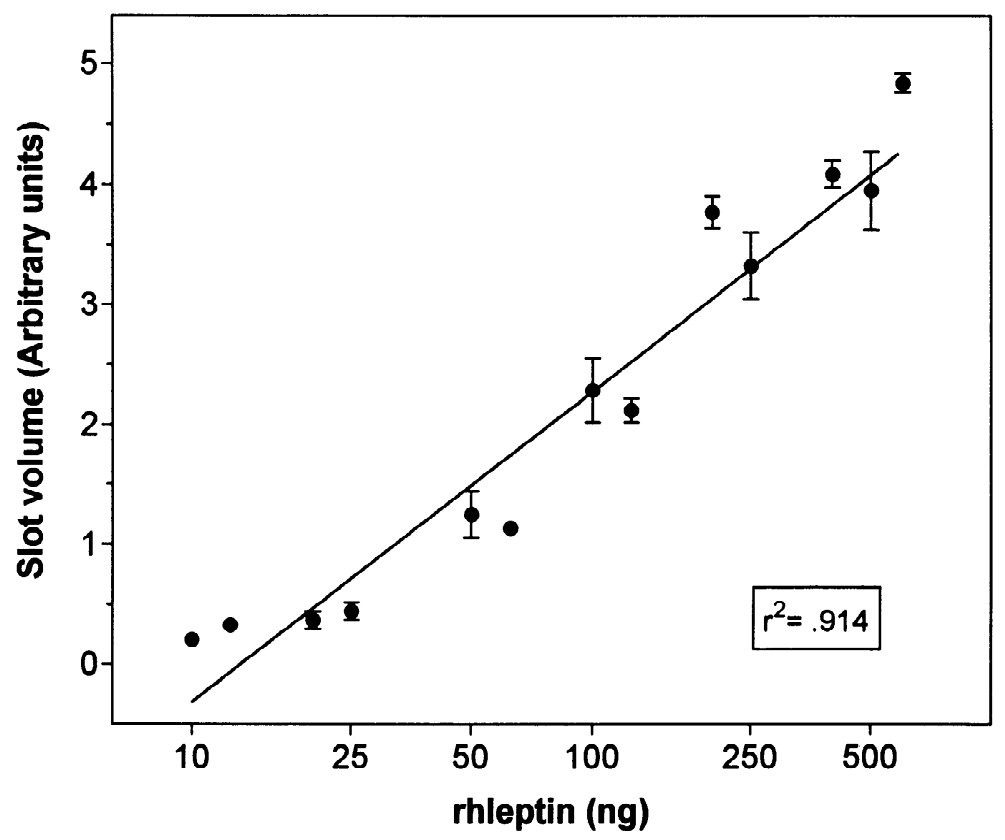

Fig. 3. Slot blot analysis of purified human recombinant leptin. A composite standard curve was constructed from the results of six separate blots with varying amounts (10-600 ng) of added protein per slot. The curve demonstrates a significant linear response $\left(r^{2}=0.914\right)$ between 20 and $500 \mathrm{ng}$ of added leptin protein with a lower limit of detection estimated at about 10-20 ng. Each value represents the mean \pm S.E.M. of two to four individual determinations and the plotted line was derived from standard linear regression analysis of the combined data. 
in a significant reduction or elimination of immunostaining for leptin (data not shown). Liver, ileum, and muscle from the same pig presented no indication of positive immunostaining for leptin with this antiserum (data not shown). In the sub-dermal regions of skin, some evidence of positive staining for leptin was evident, presumably at the junction with cells differentiating into adipocytes. Immunostaining for leptin was prominent in most adipocytes (omental and back fat tissue), in particular in interior membrane areas where two or more cells were adjacent and the nucleus was present (Fig. 4a,b). In abdominal adipose tissue (fat pad) obtained from a 4-week-old male broiler chicken, positive staining for leptin was observed in both nuclear and plasma membrane-associated regions (Fig. 4c). Unlike in the pig, leptin staining was detected in chicken liver tissue (Fig. 4d). While relative leptin expression in chickens has been shown to be higher in liver than adipose tissue [4,5], immunohistochemical staining of leptin in hepatic cytoplasm was diffuse and light as compared to adipocytes (compare Fig. 4c,d). Perhaps this reflects differences in the intracellular transit time of leptin (a secreted protein) between these two tissues. In the chicken, positive staining for leptin was apparent in nuclear as well as plasma membrane-associated regions in both adipocytes and hepatocytes (Fig. 4c,d).

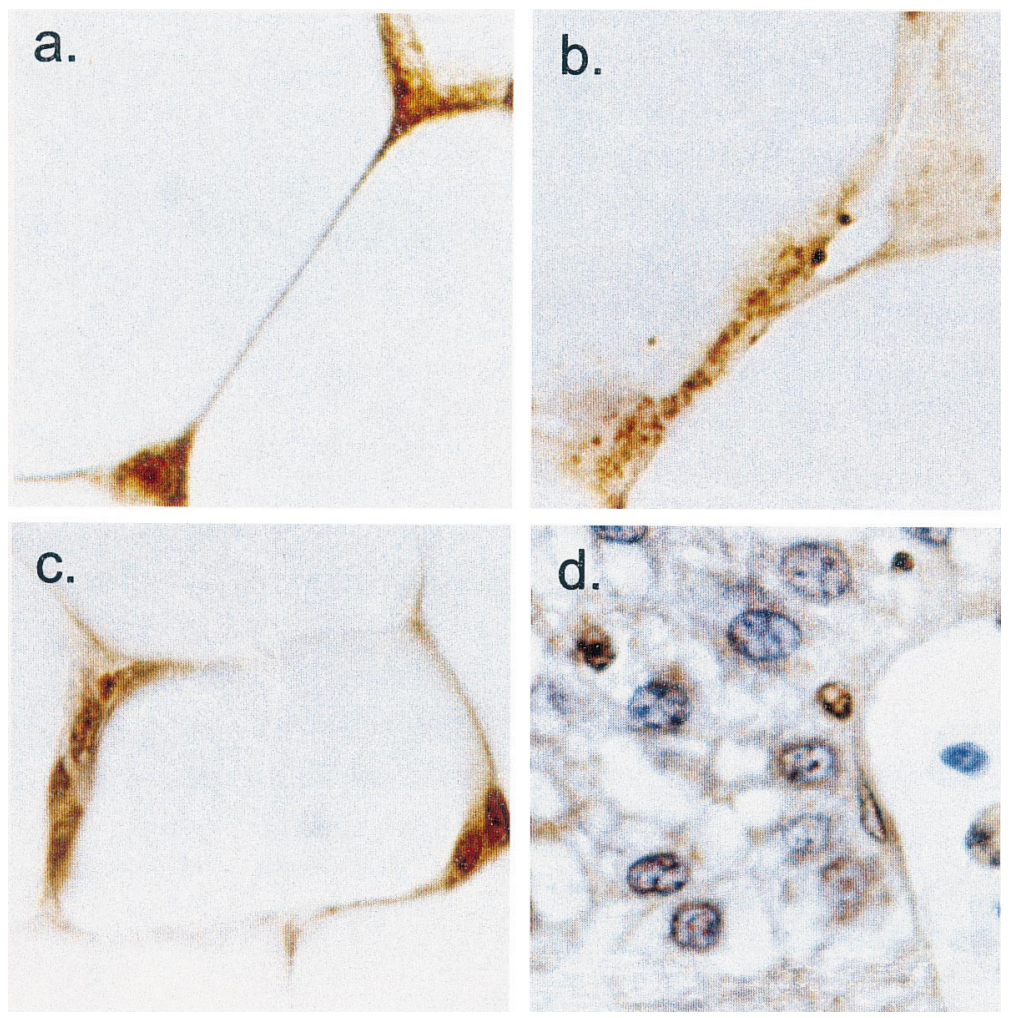

Fig. 4. Immunohistochemical localization of leptin protein in thin sections prepared from omental fat (a) and backfat (b) obtained from $80 \mathrm{~kg}$ cross-bred gilts and abdominal fat pad (c) and liver (d) collected from a 4-week-old broiler chicken. 
Table 1

Evaluation of a peptide antiserum for cross-species leptin protein analyses

\begin{tabular}{|c|c|c|}
\hline Application & Evaluation & Recommendations \\
\hline Western blot & Useful & $\begin{array}{l}\text { Dilutions up to } 1: 8000 \text {; lower limit } \\
\text { of detection in the low ng range }\end{array}$ \\
\hline Slot blot & Useful & $\begin{array}{l}\text { Dilution at } 1: 5000 \text {; lower limit of } \\
\text { detection in the } 10-20 \text { ng range, } \\
\text { but sample matrix effects may limit } \\
\text { application }\end{array}$ \\
\hline Immunohistochemistry & Useful & $\begin{array}{l}\text { Dilution at } 1: 2000 ; \text { use double } \\
\text { antibody detection method }\end{array}$ \\
\hline $\begin{array}{l}\text { Enzyme-linked } \\
\text { immunoassay }\end{array}$ & Possible & $\begin{array}{l}\text { Use as a universal capture antibody to } \\
\text { coat plates or as a universal detection } \\
\text { antibody for ELISA }\end{array}$ \\
\hline Affinity purification & Possible & For native leptin purification \\
\hline
\end{tabular}

\section{Simplified method description and future applications}

A high-titer polyclonal peptide-antiserum that recognizes intact leptin protein was produced in rabbits immunized against a KLH-conjugated synthetic peptide containing a totally conserved eight amino acid core sequence. This antiserum was employed in both Western and slot blot analyses to detect and quantify leptin protein, as well as in immunohistochemical staining of prepared thin sections from adipose and liver tissue samples. The 'universal' species recognition characteristics of this antiserum make it a potentially useful reagent for leptin immunoassay development covering a wide range of animal species, including humans, without the constraints of variable cross-reactivity that characterizes other available leptin antisera and purified antibodies. Some of the applications for this peptide antiserum are summarized in Table 1. The latter two potential uses (enzyme-linked immunoassay and affinity purification) would require further enrichment of the leptin-specific antibodies by production of an IgG-enriched fraction and/or affinity purification of the antibodies using the peptide antigen. Both of these enrichments can be readily achieved using established antibody purification techniques. A preliminary evaluation of this antiserum suggests that it may not be suitable for development of a leptin-specific radioimmunoassay. This could reflect an inability of the antibodies to form a precipitating complex with leptin protein due to the limited size of the epitope recognized. In support of this idea, the peptide antiserum was also found to be ineffective in a standard radial diffusion immunoassay (data not shown) which requires the precipitation of an antibody-antigen complex.

\section{References}

[1] Zhang Y, Proenca R, Maffei M, Barone M, Leopold L, Friedman JM. Positional cloning of the mouse obese gene and its human homologue. Nature 1994;372:425-32.

[2] Zhang F, Basinski MB, Beals JM, Briggs SL, Churgay LM, Clawson DK et al. Crystal structure of the obese protein leptin E-100. Nature 1997;387:206-9. 
[3] Kline AD, Becker GW, Churgay LM, Landen BE, Martin DK, Muth WL et al. Leptin is a four-helix bundle: secondary structure by NMR. FEBS Lett 1997;407:239-42.

[4] Taouis M, Chen J-W, Daviaud C, Dupont J, Derouet M, Simon J. Cloning the chicken leptin gene. Gene 1998;208:239-42.

[5] Ashwell CM, Czerwinski SM, Brocht DM, McMurtry JP. Hormonal regulation of leptin expression in broiler chickens. Am J Physiol 1999;276:R226-32.

[6] Caro JF, Sinha MK, Kolaczynski JW, Zhang PL, Considine RV. Leptin: the tale of an obesity gene. Diabetes 1996;45:1455-62.

[7] Tartaglia LA, Dembski M, Weng X, Deng N, Culpepper J, Devos R et al. Identification and expression cloning of a leptin receptor, OB-R. Cell 1995;83:1263-71.

[8] Flier JS, Maratos-Flier E. Obesity and the hypothalamus: novel peptides for new pathways. Cell 1998;92:437-40.

[9] Houseknecht KL, Baile CA, Matteri RL, Spurlock ME. The biology of leptin: a review. J Anim Sci 1998;76:1405-20.

[10] Houseknecht KL, Portocarrero CP. Leptin and its receptors: regulators of whole body energy homeostasis. Domest Anim Endocrinol 1998;15:457-75.

[11] Laemmli UK. Cleavage of structural proteins during the assembly of the head of bacteriophage T4. Nature 1970;227:680-5. 